\title{
Wielkanocna woda. \\ Posłowie do tłumaczenia opowiadania Uwego Johnsona na język polski
}

Uwego Johnsona Wielkanocna woda od teraz w języku polskim? I to jeszcze w dodatku w tłumaczeniu kogoś, kto ma swoje ognisko domowe niedaleko okolic, w których również rodzina Johnsona, wypędzona z Pomorza, mieszkała w okresie powojennym - w Güstrow Ernsta Barlacha, którego „słowiańsko” patrzących drzeworytów naziści nie za bardzo lubili. Było to wtedy, zanim Johnsonowie z kolei „zabrali się” na drugą stronę, zamieniając wschodnią część okrojonych Niemiec na zachodnią. Wszystko to jest konstytuującą częścią składową historii życia nazwanego ongiś „,ogólnoniemieckim” (określenie, które on sam w ogóle nie lubił) powieściopisarza Uwe Johnsona. Co prawda, Meklemburczyk Johnson był mistrzem pióra, który znał obydwa państwa niemieckie, potem żył jako wolny twórca literatury w zachodnim sektorze Berlina i dla zachodnioniemieckiego wydawnictwa pisał na tematy wschodnioniemieckie - najchętniej oczywiście w domu, który usytuowany byłby w Finlandii, w Karelii, zatem tam, gdzie jest jeszcze więcej jezior niż w jego Meklemburgii (ale letnią porą również więcej i większe komary). Wszystko to można przeczytać w jego biografii, do dzisiaj istnieje tylko jedna'.

\footnotetext{
${ }^{1}$ Bernd Neumann, Uwe Johnson (Berlin: Ullstein Verlag, 2000), w wielu wydaniach osiągalna, ale najbardziej pewna jako poprawione wydanie oficyny wydawniczej Ullstein-Taschenbuch z lutego 2000 roku. Na temat Wielkanocnej wody, tamże, 525 i n.
} 
Zatem wielkanocna woda. Jest to zwyczaj jeszcze z pogańskich czasów, który przede wszystkim w Europie (ale nie tylko, więcej o tym później) niemieccy wypędzeni kultywowali, robili to także później (właśnie szczególnie później), kiedy wojna Hitlera uczyniła ich bezdomnymi, czyli pozbawionymi małej ojczyzny ${ }^{2}$. Przykładowo ,ziemia pomorska”, jakby świeżo wydobyta ze wspomnień Johnsona i przechowywana w Archiwum Literackim w Marbach jak relikwia, składowana pod srogim spojrzeniem idealisty Schillera, w międzyczasie (i chyba słusznie) zdemaskowana jako „rewanżystowska”. A była przecież wspomnieniem o wymiarze ogólnoeuropejskim i o takim samym znaczeniu. Co się m.in. uwidacznia w tym, że ,przynoszenie wielkanocnej wody” również w zdominowanej katolicko Polsce stało się obyczajem przede wszystkim tam, gdzie sami niegdyś nieustanne wypędzani ze swoich stron znaleźli „małą ojczyznę”. I kto nie jest, również w dzisiejszej Polsce, „tak naprawdę”, patrząc przez pryzmat historii rodzinnej, wypędzonym? Gorzka i osobliwa ironia historii: „przynosić wielkanocną wodę" jako pierwotnie pogańsko-magiczny obyczaj, ale również jeszcze jeden pochodzący z utraconych przez Niemców „ziem wschodnich”, ze Śląska, Pomorza, Kraju Sudeckiego. I później ponownie tam w domu, gdzie panowanie kiedyś było niemieckie, zatem również w Szczecinie, mieście portowym położonym przy ujściu Odry, połączonym przez Zalew Szczeciński z ukochanym przez Johnsona Bałtykiem [Ostsee - AT], jego „Morzem Bałtyckim” [Baltisches Meer - AT]. Tutaj dokonano tłumaczenia Wielkanocnej wody na język polski. Ci, którzy nieustannie przez Hitlera i Stalina przepędzani między wojnami światowymi, w większości katolicy, dziedziczyli w ten sposób (jak wyjaśniono również pogański) obyczaj wielkanocny, który jak się wydaje, był bardziej charakterystyczny dla niemieckich wypędzonych po drugiej wojnie światowej. Zbratanie szczególnego rodzaju, biorąc zwłaszcza pod uwagę stosunki między Polakami i Niemcami, jest dostatecznym uzasadnieniem tego, że Wielkanocna woda Uwe Johnsona została przełożona na język polski w nadbałtyckim Stettin, które dzisiaj nosi nazwę Szczecin ${ }^{3}$.

To uwidacznia się również przy dokładniejszym przyjrzeniu się temu krótkiemu, skompresowanemu, i miejmy nadzieję, że jest to widoczne, rygorystycznie

\footnotetext{
${ }^{2}$ Por. Hanns Bechtold-Sträubli, red. Handwörterbuch des deutschen Aberglaubens [Słownik niemieckich przesąów], cz. 1, t. 6 (Berlin: de Gruyter, 1934/1935): ust. 1357-1363.

${ }^{3}$ Ogólnie do tej kwestii ,polskiego przyjęcia” Holsteinischer Courier, 16.04. 2017.
} 
skomponowanemu opowiadaniu Johnsona ${ }^{4}$. Traktuje ono o tym, że ludowe przesądy dodają ,wielkanocnej wodzie” szczególnych sił, kiedy dziewczyny i młode kobiety w nocy przed świętem wielkanocnym czerpią ze strumienia lub źródła. Oczywiście nie chodzi tu o Morze Bałtyckie. Jednak zgodnie z tęsknotą - miłością Johnsona do tych wód, Morze Bałtyckie przejmuje u niego niezbywalną funkcję źródła. Musiało nastąpić zanurzenie lub przynajmniej zwilżenie, tylko tak dziewczęta lub młode kobiety mogły wejść w posiadanie cudownego środka, który obiecuje im zarówno urodę, jak i zdrowie. Ten rozpowszechniony w północno- i wschodnioniemieckim obszarze językowym mit zostaje odniesiony przez Johnsonowskiego narratora do całej szczególnej sytuacji w roku 19465, po zakończeniu wojny w fikcyjnym ,pomorskim Jerichow”, gdzie Heinrich Cresspahl mieszka ze swoją córką Gesine, w sąsiedztwie zbiegłych rodaków volkistowskich, pod zwierzchnictwem zwycięskich Sowietów. Ojciec i córka są w uczciwej opozycji do wszystkich dyktatorskich form rządzenia, na zasygnalizowaniu tego bardzo autorowi zależało. I ten społeczny nowy początek oznacza również narracyjny początek o tyle, że Johnson tutaj po raz pierwszy konstytuuje samotnie i uparcie „świadomość Gesine Cresspahl”, co m.in., później tworzyć będzie szczególną strukturę narracyjną jego „dojrzałej” tetralogii Jahrestage. Jak to wiązało się z problematyką małżeństwa Johnsona jako specyficznej dla niego własnej problematyki życiowej, zrekonstruowano wyczerpująco we wskazanej biografii Meklemburczyka i w tym miejscu nie ma potrzeby do tego wracać. Ale za to, co konstytuuje rozwój Gesiny, by w końcu stać się samodzielną partnerką narracyjną jej „towarzysza Johnsona”, a więc coś, co w tekście Wielkanocna woda stoi przed nami w formie in statu nascendi, jako prawie książkowa demonstracja zmieniającego się stylu narracji Johnsona. Można ten rozwój opisać jako zysk lub stratę, jego ważność i zarys pozostają niezaprzeczalne. Od kompetentnego, jak zawsze partnera do dyskusji, jeszcze z powieści debiutanckiej Domniemania w sprawie Jakuba z 1959 roku, przeistacza się się Gesine - właśnie w Wielkanocnej wodzie - w (stającą się samą coraz bardziej ,,autorską"?) partnerką narracyjną równoprawną narratorowi Johnsonowi. Ona zyskuje w poetyckiej świadomości autora ciągle rosnące znaczenie, żeby na końcu zaproklamować współautorstwo

\footnotetext{
${ }^{4}$ Pierwsza edycja, Uwe Johnson, Karsch, und andere Prosa (Frankfurt nad Menem: Suhrkamp Verlag), 1964 (edition suhrkamp 59), jako tekst otwierający zbiór.

${ }^{5}$ Norbert Mecklenburg jako autor posłowia do zbioru tekstów Johnsona (Karsch, 1990), 97 przyjął błędnie, że akcja opowiadania rozgrywa się w Wielkanoc 1945 roku.
} 
i swojego „towarzysza pisarza” potraktować jako zleceniobiorcę i wręcz jako dostawcę usług ${ }^{6}$.

W każdym razie późniejsze monumentalne Jahrestage I-IV (1970 i lata następne) są nie do wyobrażenia bez wielokrotnie deklarowanego zamiaru przedstawienia już wymienionej „świadomość Gesine Cresspahl” (u niego ciągle pisane bez dopełniacza „„") ${ }^{7}$. Jednak ten proces zaczął się „całkiem prawidłowo" wycieczką Gesiny po wielkanocną wodę już nie w niemieckim Jerichow, w określonych okolicznościach, których nowi polscy osiedleńcy mogli wówczas doznać w Szczecinie, co być może u nich również wywołało skłonność do pogańskich i magicznych ćwiczeń wielkanocnych? Ten projekt, mający wyeksponować „świadomość Gesine Cresspahl”, posiada w związku z tym w twórczości Meklemburczyka długą prehistorię. W powieści debiutanckiej tylko zaanonsowana, teraz wyposażona w indywidualną historię Gesine znalazła się w centrum opowiadania Wielkanocna woda. Młoda, szczupła, trzynastoletnia dziewczynka, jeszcze w okresie dojrzewania, stanowi punkt wyjścia rozwoju - od poliperspektywicznie ograniczonej wcześniejszej Gesine, do jej strony „autorsko” opowiedzianej, późniejszej, raczej dominującej Gesine z powieści Jahrestage, w jej całej epickiej rozciągłości.

Tutaj ma miejsce w zdumiewającym, równocześnie restauracyjnym, jak i rewolucyjnym procesie nowoczesnej sztuki narracyjnej autoryzowanie wymyślonej osoby do bycia równouprawnionym partnerem autora, narodzonego z koincydencji gruntownie zmienionej tematyki krajobrazowej i społecznej z wzmiankowanym radykalnym zrewolucjonizowaniem stylu narracji. „W szczególności opowiadanie Wielkanocna woda nadaje się do uwypuklenia funkcji łącznika" ". Trzymajmy się tej wypowiedzi, wzbogaćmy ją w dalsze fakty. Johnson żył wówczas od wielu lat w Berlinie Zachodnim, opublikował dwie powieści, które odniosły sukces, co jemu jako pisarzowi awangardowemu z oficyny Suhrkampa dało wysokie uznanie i już wcześniej przyniosło przyjaźń wydawcy Siegfrieda Unselda. Mimo tego ta nowa, jeszcze niezwykle młoda gwiazda literatury popadła w kryzys twórczy, który temu dwudziestodziewięciolatkowi przysporzył kłopotów. Paradoksalnie

\footnotetext{
${ }^{6}$ Por. Ulrich Krellner, Was ich im Gedächtnis ertrage. Untersuchungen zum Erinnerungskonzept von Johnsons Erzählwerk (Würzburg: Königshausen und Neumann, 2003), 207 i n.

${ }^{7}$ Por. Dieter E. Zimmer, „Eine Bewusstseinsinventur”, w: Michael Bengel, red., Johnsons Jahrestage (Frankfurt nad Menem: Suhrkamp Verlag, 1985), 99.

${ }^{8}$ Ulrich Krellner, „Gesines österliche Auferstehung...”, w: Deutsche Vierteljahresschrift für Geistesgeschichte 4 (2012), 86: 612.
} 
brakowało mu opresyjnego systemu NRD, a nowa wolność w Berlinie Zachodnim oddziaływała na niego paraliżująco. Do tego doszedł, jest to istotne, kolejny aspekt: od roku 1961 i wzniesienia Muru Berlińskiego w małżeństwie Johnsonów narastał kryzys, potęgowany paranoicznymi atakami zazdrości. Zamierzał rozwiązać przytłaczający go kryzys w ten sposób, że wyniósł swoją żonę, zwłaszcza w okresie późniejszej amerykańskiej/angielskiej emigracji do roli nowej partnerki w pisaniu i przypominaniu. To „była” jednak ta Gesine, której inicjację przeprowadził w fabule utworu Wielkanocna woda. Opowiadanie Johnsona nie jest właśnie dlatego jednowymiarową spokojną relacją z wydarzenia, co niektórzy założyli ${ }^{9}$, lecz opowiada bardzo dobitnie o zdarzeniu, jak dorastająca osoba w czasach bezprawia lat powojennych uczy się bronić swojej skóry, czytaj: przeciwko zgwałceniu: przy pomocy bezkompromisowego kopnięcia w zagrażająco wyciągające się męskie czułe miejsca. To doświadczenie w znacznie większym stopniu ukształtowało życie Gesine i było ważniejszym przeżyciem niż wszystkie wielkanocne (Morze Bałtyckie) wodne czary, jakiejkolwiek pogańskiej proweniencji, mogłyby być - stało się doświadczeniem inicjacyjnym i w związku z tym nabrało znaczenia, które później w Jahrestage - nie bezpośrednio lecz wielokrotnie - będzie potwierdzone. Przy tej okazji opowiadanie Wielkanocna woda zostało stworzone bardzo szybko, Johnson nie był wówczas opieszałym dostarczycielem tekstów, nim stał się później w trakcie powstawania tetralogii Jahrestage. Wielkanocna woda została napisana jednym tchem w przeciągu dobrego tygodnia i przesłana osobiście Siegfriedowi Unseldowi. Patrząc z perspektywy Jahrestage - to wielkie dzieło jest dlatego jednią, ponieważ zostało wydarte coraz bardziej rosnącemu oporowi „Gesiny” - i zostało dokończone samotnie. Ta już wymieniona biografia Uwego Johnsona ma w tym swój udział; poddana została werdyktowi niektórych krytyków literackich i dlatego nie mogła ukazać się w oficynie wydawniczej Suhrkampa ${ }^{10}$.

Ponadto zgadza się w sumie to, co zauważył Ulrich Krellner, że akademicka recepcja fabuły Wody wielkanocnej zachodziła prawie wyłącznie w aspektach związków biografii z dziełem i technik narracyjnych i poprzez to zostało

\footnotetext{
${ }^{9}$ Według Ulricha Krellnera („Gesines”, 619 i 622) przede wszystkim Norbert Mecklenburg i również Reinhard Baumgart.

${ }^{10}$ Również w tym przypadku centralną postacią była Gesina; przede wszystkim Reinhard Baumgart widział w niej w rzeczy samej bliskość do „utraty środka” i poprzez to przesunął Johnsona „,na plan dalszy, w którym nie powinien znaleźć się. Por. też: Krellner, „Gesines”, 622: „Przygoda Gesiny ani nie kończy się z wszystkich punktów widzenia dobrze, ani jej przeżycia nie nadają się do kompensacji Sedelmayerowskich uczuć straty".
} 
przeoczone, że w fabule istnieje również aranżacja centralnego bazowego doświadczenia życiowego Gesiny. Z tej racji zaleca się również zastosowanie się do następującej konkluzji tego badacza: „Ponieważ nie tylko znaczenie Wielkanocnej wody jako historii inicjacyjnej pozostało nietematyczne, lecz poza tym znajduje się w obiegu kilka problematycznych poglądów na temat «idyllicznej» treści, opłaca się jeszcze raz dokładnie przeanalizować opowiadanie, które pokazuje ponowne przyswojenie centralnej figury Jahrestage Johnsona" "11. I ta konstatacja kończy przedłożone tutaj, zasługujące na uznanie polskie tłumaczenie tego tekstu, które mogłoby być preludium do przekładu również Jahrestage na język polski. To byłaby eminentna korzyść.

Ttumaczenie: Andrzej Talarczyk

\section{Cytowanie}

Bernd Neumann, „«Wielkanocna woda». Posłowie do tłumaczenia opowiadania Uwego Johnsona najęzyk polski”, PrzeglądZachodniopomorski36(2021), 65:429-434,DOI: 10.18276/pz.2021.36-17.

\footnotetext{
${ }^{11}$ Tamże, 615.
} 